Prepared in cooperation with the lowa Department of Transportation and lowa Highway Research Board (Project HR-140)

\title{
Flood of June 8-9, 2008, Upper lowa River, Northeast lowa
}

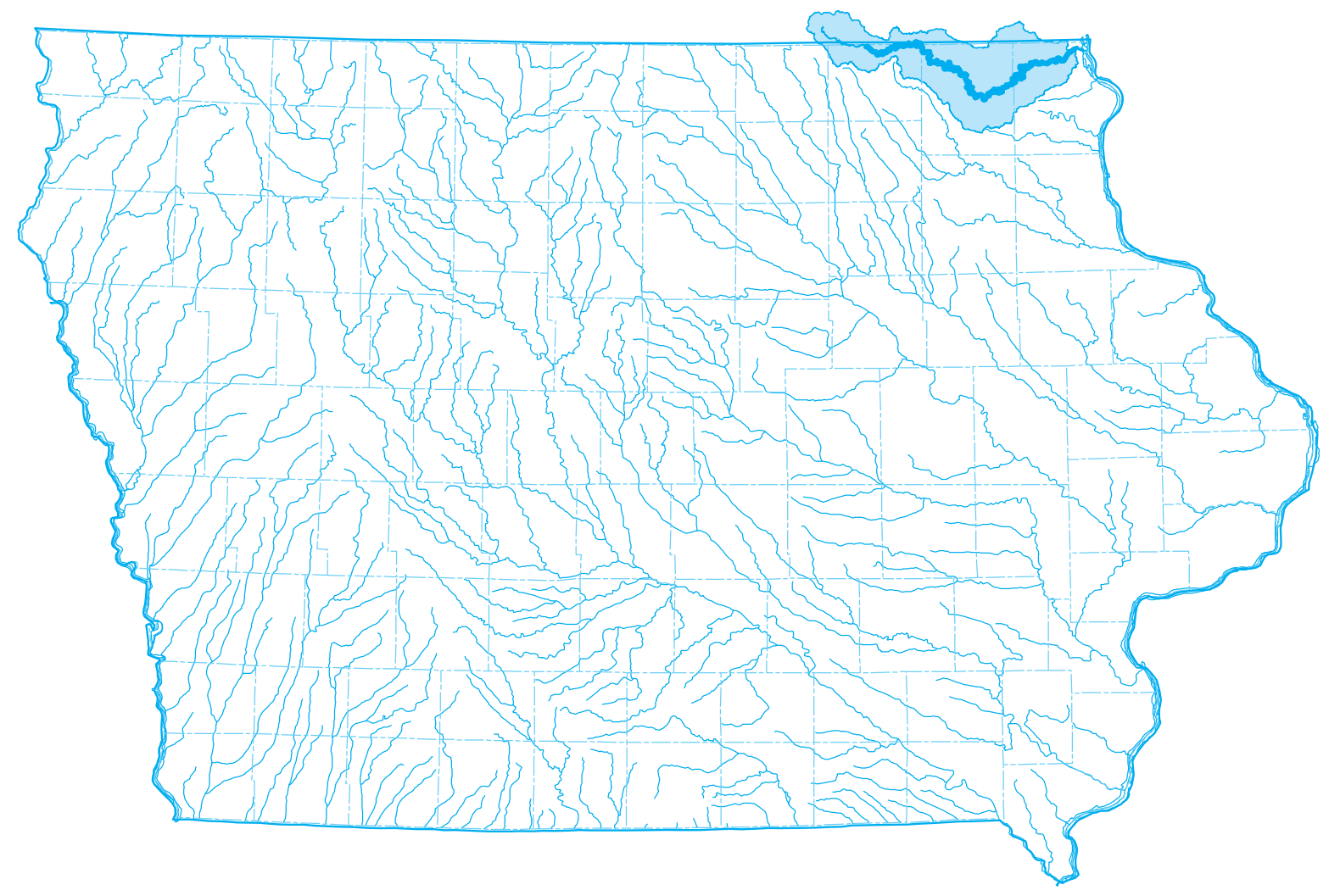

Open-File Report 2010-1087 
Cover. Map of lowa showing location of Upper lowa River Basin and river reach profiled in the report. 


\section{Flood of June 8-9, 2008, Upper lowa River, Northeast lowa}

By Edward E. Fischer and David A. Eash

Prepared in cooperation with the lowa Department of Transportation and lowa Highway Research Board (Project HR-140)

Open-File Report 2010-1087 


\title{
U.S. Department of the Interior \\ KEN SALAZAR, Secretary \\ U.S. Geological Survey \\ Marcia K. McNutt, Director
}

\section{U.S. Geological Survey, Reston, Virginia: 2010}

\author{
For more information on the USGS — the Federal source for science about the Earth, its natural and living resources, \\ natural hazards, and the environment, visit http://www.usgs.gov or call 1-888-ASK-USGS \\ For an overview of USGS information products, including maps, imagery, and publications, \\ visit http://www.usgs.gov/pubprod \\ To order this and other USGS information products, visit http://store.usgs.gov
}

Any use of trade, product, or firm names is for descriptive purposes only and does not imply endorsement by the U.S. Government.

Although this report is in the public domain, permission must be secured from the individual copyright owners to reproduce any copyrighted materials contained within this report.

Suggested citation:

Fischer, E.E., and Eash, D.A., 2010, Flood of June 8-9, 2008, Upper lowa River, Northeast lowa: U.S. Geological Survey Open-File Report 2010-1087, 17 p. with app. 


\section{Contents}

Abstract
Introduction.
Purpose and Scope
Acknowledgments
Study Basin
Flood Profile
Summary
References Cited
Appendix List of bench marks and reference points

\section{Figures}

1. Map showing the Upper lowa River Basin and lines of equal rainfall for 72 hours ending 11 p.m., June 8, 2008

2. Discharge hydrographs for June $7-11,2008$, for the three streamgages on the Upper lowa River, northeast lowa .........................................................................

3-5. Graphs showing-

3. Profile of the June 8-9, 2008, flood in the Upper lowa River, river miles 3 to 127

4. Profile of the June 8-9, 2008, flood in the Upper lowa River, river miles 3 to 65 9

5. Profile of the June 8-9, 2008, flood in the Upper lowa River, river miles 65 to 127

\section{Tables}

1. Maximum discharges and corresponding flood-probability ranges for selected peak flows at streamgages in the Upper lowa River Basin, northeast lowa.

2. Flood probability and equivalent flood-recurrence interval for selected probabilities

3. Locations and elevations of high-water marks used in the Upper lowa River flood profile, flood of June 8-9, 2008 


\section{Appendix Table}

1. Bench marks and reference points used in the Upper lowa River flood profile, flood of June 8-9, 2008.

\section{Conversion Factors and Datums}

Inch/Pound to SI

\begin{tabular}{|c|c|c|}
\hline Multiply & By & To obtain \\
\hline \multicolumn{3}{|c|}{ Length } \\
\hline inch (in.) & 2.54 & centimeter $(\mathrm{cm})$ \\
\hline foot $(\mathrm{ft})$ & 0.3048 & meter (m) \\
\hline mile (mi) & 1.609 & kilometer $(\mathrm{km})$ \\
\hline \multicolumn{3}{|c|}{ Area } \\
\hline square mile $\left(\mathrm{mi}^{2}\right)$ & 2.590 & square kilometer $\left(\mathrm{km}^{2}\right)$ \\
\hline \multicolumn{3}{|c|}{ Flow rate } \\
\hline cubic foot per second $\left(\mathrm{ft}^{3} / \mathrm{s}\right)$ & 0.02832 & cubic meter per second $\left(\mathrm{m}^{3} / \mathrm{s}\right)$ \\
\hline
\end{tabular}

Elevation or vertical coordinate information is referenced to the National Geodetic Vertical Datum of 1929 (NGVD 1929). Elevation refers to distance above or below NGVD 1929. NGVD 1929 can be converted to the North American Vertical Datum of 1988 (NAVD 88) by using the National Geodetic Survey conversion utility available at $h t t p: / / w w w . n g s . n o a a . g o v / T O O L S / V e r t c o n /$ vertcon.html.

Horizontal coordinate information is referenced to the North American Datum of 1983 (NAD 83).

Water year is the 12-month period from October 1 through September 30. The water year is designated by the calendar year in which the water year ends and that includes 9 of the 12 months. Thus, the water year ending September 30, 2008, is called the "2008 water year." 


\title{
Flood of June 8-9, 2008, Upper lowa River, Northeast lowa
}

\author{
By Edward E. Fischer and David A. Eash
}

\begin{abstract}
Major flooding occurred June 8-9, 2008, in the Upper Iowa River Basin in northeast Iowa following severe thunderstorm activity over the region. About 7 inches of rain were recorded for the 48 -hour period ending 4 p.m., June 8 , at Decorah, Iowa; more than 7 inches of rain were recorded for the 48-hour period ending 7 a.m., June 8, at Dorchester, Iowa, about 17 miles northeast of Decorah. The maximum peak discharge measured in the Upper Iowa River was 34,100 cubic feet per second at streamgage 05387500 Upper Iowa River at Decorah, Iowa. This discharge is the largest discharge recorded in the Upper Iowa River Basin since streamgaging operations began in the basin in 1914 . The flood-probability range of the peak discharge is 0.2 to 1 percent. High-water marks were measured at 15 locations along the Upper Iowa River between State Highway 26 near the mouth at the Mississippi River and U.S. Highway 63 at Chester, Iowa, a distance of 124 river miles. The high-water marks were used to develop a flood profile.
\end{abstract}

\section{Introduction}

Severe thunderstorms following a wetter than usual spring caused record flooding in the Upper Iowa River in northeast Iowa June 8-9, 2008. Fields were flooded and highways were closed throughout the basin. Some roads were washed out. Maximum peak discharges of record were measured at each of the three streamgages on the Upper Iowa River. The storms were part of a series of unusually intense spring rainfall that also caused flooding in other major river basins in the State and throughout the midwestern United States (National Climatic Data Center, 2008).

\section{Purpose and Scope}

This report is part of an on-going program of preparing water-surface profiles of major floods on streams in Iowa. The program is in cooperation with the Iowa Department of Transportation (Iowa DOT) and the Iowa Highway Research Board (Research Board project HR-140). A list of other Iowa flood profile reports can be obtained by accessing http://ia.water. usgs.gov/projects/profiles/.

This report provides information about the thunderstorms, resulting flooding June 8-9, 2008, in the Upper Iowa River Basin, and estimated flood-probability ranges at the three continuous-record streamgages and two crest-stage gages (CSG) in the basin. High-water marks (HWM) at selected sites along the Upper Iowa River are presented in a flood profile from State Highway 26 near the mouth of the Upper Iowa River at the Mississippi River to U.S. Highway 63 at Chester, Iowa, a distance of 124 river miles.

\section{Acknowledgments}

The authors acknowledge the work and assistance of the following U.S. Geological Survey (USGS) personnel in collecting the HWM data and creating the base map: S. Mike Linhart, Scott Thul, Kevin Townsend, and Rochelle Galer. The authors also acknowledge the work of the Iowa State Climatologist, Harry Hillaker, for creating the rainfall isohyetal map.

\section{Study Basin}

The Upper Iowa River is a tributary of the Mississippi River in northeast Iowa (fig. 1). The headwaters are in Mower County, Minnesota, and a small part of Mitchell County, Iowa. The river flows east primarily through Howard, Winneshiek, and Allamakee Counties in Iowa. Short segments of the river lie in Fillmore County, Minnesota, as the river channel meanders across the Iowa/Minnesota border. Northern parts of the basin also lie in Houston County, Minnesota, near the east end of the basin. The river mouth is at the Mississippi River in northeast Allamakee County. The drainage area at the mouth is 999 square miles $\left(\mathrm{mi}^{2}\right.$ ) (Natural Resources Conservation Service, 2009).

The Upper Iowa River Basin lies in two of Iowa's landform regions, the Iowan Surface and the Paleozoic Plateau (Prior, 1991; not shown in figure 1). The headwaters of the river are on the Iowan Surface; the river crosses onto the Paleozoic Plateau near Lime Springs. The topography of the Iowan Surface "*** appears slightly inclined to gently rolling with long slopes, low relief, and open views to the horizon" 

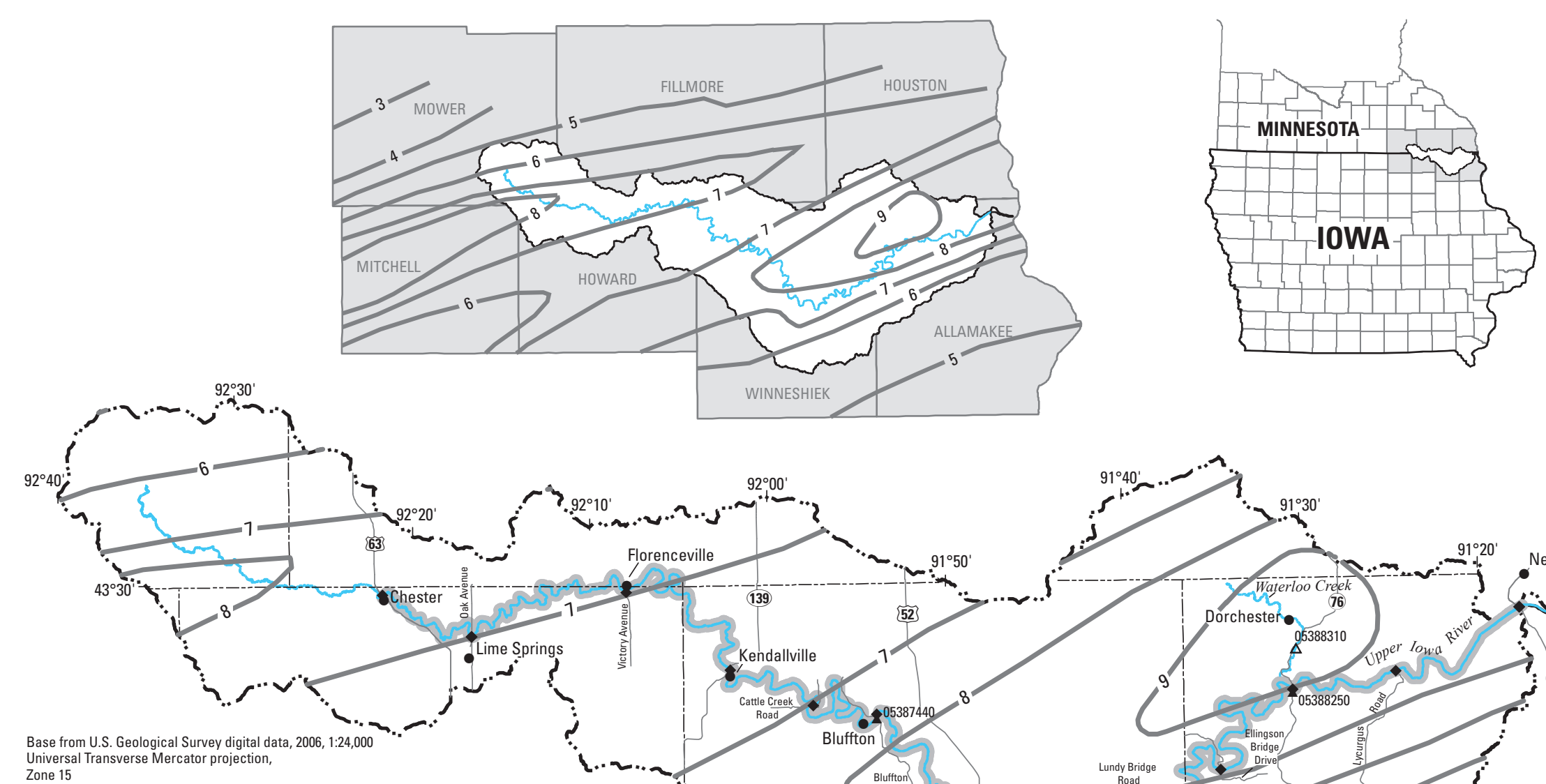

Universal Transverse Mercator projection,
Zone 15

\section{EXPLANATION}

River reach profiled in this report

-7- Line of equal rainfall-For 72 hours ending 11 p.m. June 8,2008 , in inches, variable intervals (Harry Hillaker, State Climatologist, Iowa Department of Agriculture and Land Stewardship, written commun., 2009)

-... Basin boundary

${ }_{05387440}^{\Delta}$ Streamgage and station number

${ }^{05387490} \Delta \quad$ Crest-stage gage and station number

- Flood-profile point

Figure 1. The Upper lowa River Basin and lines of equal rainfall for 72 hours ending 11 p.m., June 8, 2008. 
(Prior, 1991). In contrast, the topography of the Paleozoic Plateau “*** include[s] abundant rock outcroppings, a near absence of glacial deposits, many deep, narrow valleys containing cool, fast-flowing streams, and more woodlands" (Prior, 1991). In the eastern one-half of Allamakee County, the Upper Iowa River flood plain becomes wide and flat before the river empties into the Mississippi River. More-extensive descriptions of the landform regions and physiography of the Upper Iowa River Basin are available from Prior (1991) and the Iowa Natural Resources Council (1958).

Land use in the Upper Iowa River Basin primarily is agricultural in the Iowan Surface landform region, and agricultural and forest in the Paleozioc Plateau landform region (Prior, 1991). The Upper Iowa River flows through Decorah, the only urban community in the basin, in Winnishiek County (fig. 1). Parts of the city are protected by levees. The Upper Iowa River is a popular recreation venue for much of its length.

\section{Description of Storms and Flood}

Intense rainfall fell over northeast Iowa and southeast Minnesota June 7-8, 2008. The rainfall amount at Decorah was 6.80 inches (in.) for the 48 -hour period ending 4 p.m., June 8; at Dorchester it was 7.30 in. for the 48 -hour period ending 7 a.m., June 8 . Three days previously on June 5 , slightly more than 2 in. of rainfall were recorded at Decorah, which helped saturate the soil in the region (Hillaker, 2008). The storms were part of an exceptionally wet period from May 29 through June 12, when an Iowa statewide average of 9.03 in. of rain fell (Hillaker, 2008); the normal statewide average for the same period is 2.45 in. (Hillaker, 2008). A 72-hour isohyetal map compiled by the Iowa State Climatologist for the period ending 11 p.m., June 8, 2008, is shown in figure 1 (Harry Hillaker, written commun., 2009).

The intense rainfall caused widespread flooding throughout three counties in northeast Iowa June 8-9, 2008. Estimated county-wide damage to roads and bridges was more than $\$ 1.3$ million in Howard County (Nick Rissman, Howard County Engineer, written commun., 2009), \$1.5 million in Winneshiek County (Lee Bjerke, Winneshiek County Engineer, written commun., 2009), and $\$ 650,000$ in Allamakee County (Brian Ridenour, Allamakee County Engineer, written commun., 2009). Although no major bridges were destroyed, numerous bridge approach roads were overtopped, some of which were washed out. The levees in Decorah remained intact during the flood, except for a levee near Luther College on the northwest side of the city. The levee that failed was adjacent to several college athletic facilities (Luther College Public Information Office, 2008). With the exception of the athletic facilities, high water in Decorah was limited to the flood inundation areas delineated in a flood-plain study that recently was completed (Christiansen and Eash, 2008). Roads and bridges in southeast Minnesota similarly were affected by the intense rainfall
(Kjersti Anderson, Hydraulics Engineer, Minnesota Department of Transportation, written commun., 2009).

Maximum peak discharges of record were measured at all three continuous-record streamgages on the Upper Iowa River. The streamgages are 05387440 Upper Iowa River at Bluffton, Iowa; 05387500 Upper Iowa River at Decorah, Iowa; and 05388250 Upper Iowa River near Dorchester, Iowa (fig. 1). Discharge hydrographs for June 7-11, 2008, are shown in figure 2 . The peak discharges at the streamgages were determined from rating curves that were verified by discharge measurements made near the time of occurrence of the respective peaks. The maximum recorded discharge in the basin was 34,100 cubic feet per second $\left(\mathrm{ft}^{3} / \mathrm{s}\right)$, which was measured at 05387500 Upper Iowa River at Decorah, Iowa. This discharge is the largest discharge recorded in the Upper Iowa River Basin since streamgaging operations began in the basin in 1914 (table 1). A flood of similar magnitude occurred in the basin in 1941 when a discharge of $30,400 \mathrm{ft}^{3} / \mathrm{s}$ was recorded at 05388250 Upper Iowa River near Dorchester, Iowa (U.S. Geological Survey, 2009).

A maximum peak discharge of record also was recorded at one of two CSGs that are on tributaries to the Upper Iowa River. A CSG measures the maximum stage of the water, from which the discharge is determined using a stage-discharge table. The CSGs are 05387490 Dry Run Creek near Decorah, Iowa, and 05388310 Waterloo Creek near Dorchester, Iowa (fig. 1). The maximum discharge in Dry Run Creek was $5,820 \mathrm{ft}^{3} / \mathrm{s}$, which was the largest discharge since the CSG was installed in 1978. The maximum discharge in Waterloo Creek was $8,800 \mathrm{ft}^{3} / \mathrm{s}$, which was the second largest discharge since the CSG was installed in 1966.

The 2008 flood-peak discharges for the three streamgages and the two CSG stations are listed in table 1. Selected prioryear peak discharges are included in the table for comparison purposes. Also included in the table are data from discontinued streamgage 05388000 Upper Iowa River near Decorah, Iowa, which was located about 4.5 miles (mi) downstream from Decorah. The streamgage was operated during 1919 through 1927 and 1933 through 1951 and was discontinued when the streamgage in Decorah was installed. The peak-discharge data from the discontinued streamgage were used to extend the peak-discharge record at the Decorah streamgage for the purpose of estimating flood-probability discharges.

Flood-probability ranges for the maximum peak discharges at the three Upper Iowa River streamgages and the two tributary CSG stations are included in table 1. Flood probability is an estimate of the likelihood of a flood of specific magnitude occurring in any 1 year, and flood-probability range expresses the uncertainty of estimating precise flood probabilities. The reporting ranges are: greater than 10 percent, 4 to 10 percent, 2 to 4 percent, 1 to 2 percent, 0.2 to 1 percent, and less than 0.2 percent. The range is determined by the estimated flood-probability discharges that bracket the observed floodpeak discharge. If the observed peak discharge is the same value as an estimated flood-probability discharge, the lower flood-probability range is used. 

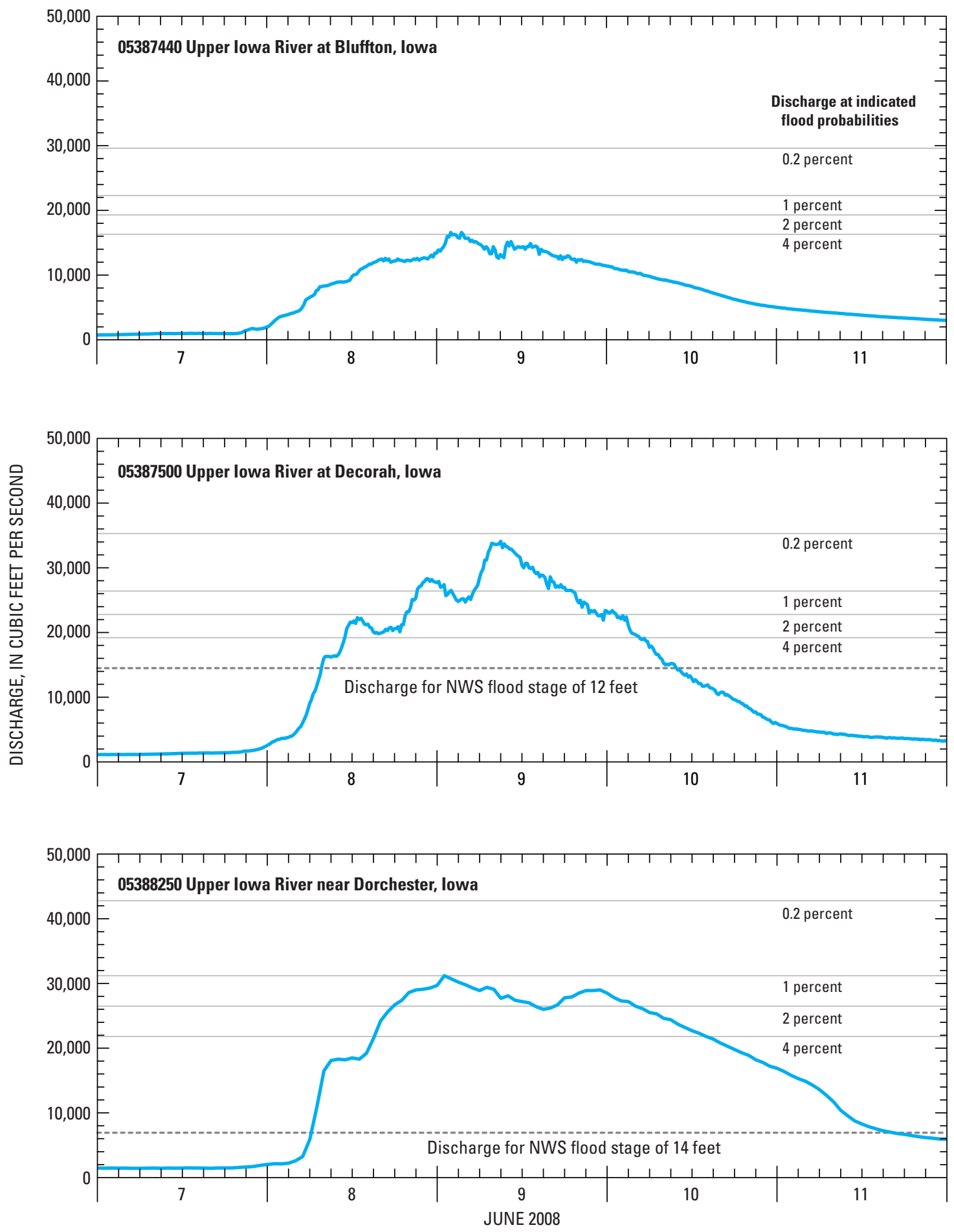

Figure 2. Discharge hydrographs for June 7-11, 2008, for the three streamgages on the Upper lowa River, northeast lowa. Also shown are flood probabilities in percent at each streamgage and discharges corresponding to the National Weather Service (NWS) flood stage at two streamgages. 
Table 1. Maximum discharges and corresponding flood-probability ranges for selected peak flows at streamgages in the Upper lowa River Basin, northeast lowa.

$\left[\mathrm{mi}^{2}\right.$, square miles; ft, feet; $\mathrm{ft}^{3} / \mathrm{s}$, cubic feet per second; e, estimated]

\begin{tabular}{|c|c|c|c|c|c|c|}
\hline $\begin{array}{l}\text { Streamgage number } \\
\text { and name }\end{array}$ & $\begin{array}{l}\text { Peak-flow record } \\
\text { (water years) }\end{array}$ & $\begin{array}{l}\text { Drainage } \\
\text { area } \\
\left(\mathrm{mi}^{2}\right)\end{array}$ & Date of peak & $\begin{array}{l}\text { Peak } \\
\text { stage } \\
\text { (ft) }\end{array}$ & $\begin{array}{c}\text { Peak } \\
\text { discharge } \\
\left(\mathrm{ft}^{3} / \mathrm{s}\right)\end{array}$ & $\begin{array}{c}\text { Flood-probability } \\
\text { range }^{\text {a }} \\
\text { (percent) }\end{array}$ \\
\hline $\begin{array}{l}05387440 \text { Upper Iowa } \\
\text { River at Bluffton, Iowa }\end{array}$ & 2003-08 & 367 & 06/09/2008 & 15.49 & 16,600 & ${ }^{\mathrm{b}} 2-4$ \\
\hline $\begin{array}{c}05387490 \text { Dry Run Creek } \\
\text { near Decorah, Iowa }\end{array}$ & $1978-2008$ & 21.0 & 06/08/2008 & 21.53 & 5,820 & $1-2$ \\
\hline $\begin{array}{l}05387500 \text { Upper Iowa } \\
\text { River at Decorah, Iowa }\end{array}$ & $1952-2008$ & 511 & $\begin{array}{l}03 / 27 / 1961 \\
08 / 17 / 1993 \\
06 / 09 / 2008\end{array}$ & $\begin{array}{r}13.08 \\
\mathrm{e} 14.35 \\
17.90\end{array}$ & $\begin{array}{r}20,200 \\
\mathrm{e} 20,500 \\
34,100\end{array}$ & $\begin{array}{l}{ }^{c} 2-4 \\
{ }^{c} 2-4 \\
{ }^{c} 0.2-1\end{array}$ \\
\hline $\begin{array}{r}05388000 \text { Upper Iowa } \\
\text { River near Decorah, } \\
\text { Iowa (discontinued) }\end{array}$ & $\begin{array}{c}1914 \\
1919-27 \\
1933-51\end{array}$ & 568 & 05/29/1941 & 15.20 & 28,500 & ${ }^{\mathrm{d}} 0.2-1$ \\
\hline $\begin{array}{l}05388250 \text { Upper Iowa } \\
\text { River near Dorchester, } \\
\text { Iowa }\end{array}$ & $\begin{array}{c}1941 \\
1976-95 \\
1997-2008\end{array}$ & 770 & $\begin{array}{l}05 / 31 / 1941 \\
08 / 17 / 1993 \\
06 / 09 / 2008\end{array}$ & $\begin{array}{l}21.80 \\
20.00 \\
22.46\end{array}$ & $\begin{array}{l}\mathrm{e} 30,400 \\
22,000 \\
31,200\end{array}$ & $\begin{array}{c}1-2 \\
2-4 \\
0.2-1\end{array}$ \\
\hline $\begin{array}{c}05388310 \text { Waterloo Creek } \\
\text { near Dorchester, Iowa }\end{array}$ & 1966-2008 & 43.6 & $\begin{array}{l}07 / 01 / 1978 \\
06 / 08 / 2008 \\
\end{array}$ & $\begin{array}{l}14.80 \\
14.57 \\
\end{array}$ & $\begin{array}{l}9,380 \\
8,800 \\
\end{array}$ & $\begin{array}{l}2-4 \\
2-4 \\
\end{array}$ \\
\hline
\end{tabular}

${ }^{a}$ Flood-probability ranges reflect the uncertainty of estimating flood-probability discharges. The flood probability is calculated using established techniques but then reported in one of the following ranges: greater than 10 percent, 4 to 10 percent, 2 to 4 percent, 1 to 2 percent, 0.2 to 1 percent, and less than 0.2 percent. Unless noted otherwise, flood-probability ranges are based on a weighted average of two independent probability estimates. The WIE (weighting of independent estimates) program was used to estimate flood probabilities following guidelines in Appendix 8 of Bulletin 17B (Interagency Advisory Committee on Water Data, 1982; Charles Berenbrock and Tim Cohn, U.S. Geological Survey, written commun., 2008). The WIE program uses the variance and estimate of the Bulletin 17B station-probability analysis and the variance and estimate of the regional-regression probability calculation (Eash, 2001) to compute a weighted probability estimate and variance at a streamgage.

${ }^{\mathrm{b} C}$ Computed using regional-regression equations (Eash, 2001) because of short peak-flow record.

'Flood-probability range computation based on 86 years of record. The additional record was obtained from discontinued streamgaging station 05388000 Upper Iowa River near Decorah, Iowa, which was located about 4.5 miles downstream from the current site. The additional peak-flow data were adjusted downward by area-weighting to account for the difference in drainage area between the two sites.

dFlood-probability range computation based on 86 years of record. The additional record was obtained from streamgaging station 05388250 Upper Iowa River at Decorah, Iowa, which is located about 4.5 miles upstream from the discontinued streamgaging station site. The additional peak-flow data were adjusted upward by area-weighting to account for the difference in drainage area between the two sites.

${ }^{\mathrm{e} D i s c h a r g e}$ is a historic peak. 
The estimated 4-, 2-, 1-, and 0.2-percent flood-probability discharges at each of the three Upper Iowa River streamgages are shown in figure 2 as horizontal lines; the flood-probability ranges are the areas between the lines. The flood-probability discharges at 05387440 Upper Iowa River at Bluffton, Iowa, were calculated using regional-regression equations (Eash, 2001) because there are less than 10 years of peak-flow record. The flood-probability discharges at 05387500 Upper Iowa River at Decorah, Iowa, and 05388250 Upper Iowa River near Dorchester, Iowa, were calculated using the Weighting of Independent Estimates (WIE) program (Charles Berenbrock and Tim Cohn, U.S. Geological Survey, written commun., 2008) following guidelines in Appendix 8 of Bulletin 17B (Interagency Advisory Committee on Water Data, 1982).

Flood probabilities formerly were reported as floodrecurrence intervals expressed in years. For example, a 1-percent flood-probability discharge is the same as the 100-year flood recurrence-interval discharge. But because of widespread confusion caused in recent years by two or more "100-year floods" occurring in a period of much less than 100 years, the scientific and engineering community has begun expressing the annual likelihood of occurence of flood discharges as a probability. Percent probablity is the inverse of the recurrence interval multiplied by 100 . Selected flood probabilities and equivalent flood-recurrence intervals are listed in table 2 .

Table 2. Flood probability and equivalent flood-recurrence interval for selected probabilities.

\begin{tabular}{cc}
\hline $\begin{array}{c}\text { Flood probability } \\
\text { (percent) }\end{array}$ & $\begin{array}{c}\text { Recurrence interval } \\
\text { (years) }\end{array}$ \\
\hline 20 & 5 \\
10 & 10 \\
4 & 25 \\
2 & 50 \\
1 & 100 \\
.5 & 200 \\
.2 & 500 \\
\hline
\end{tabular}

For informational purposes, also shown on two of the hydrographs, are the discharges corresponding to National Weather Service (NWS) designated flood stages (fig. 2). The flood stages represent "Minor flooding - minimal or no property damage, but possibly some public threat" (http:// www.crh.noaa.gov/ahps $2 / p d f / h y d r o g r a p h \_t e r m i n o l o g y . p d f$, accessed February 1, 2010). The discharges corresponding to the NWS flood stages were determined from the respective USGS stage-discharge rating curves in use at the time of the flood. At streamgage 05387500 Upper Iowa River at Decorah, Iowa, the NWS flood stage is 12 feet (ft), discharge
14,500 ft $3{ }^{3} / \mathrm{s}$ (http://www.crh.noaa.gov/ahps2/hydrograph.php? $w f o=\operatorname{arx} \&$ gage $=$ dehi4\&view $=1,1,1,1,1,1$, accessed February $1,2010)$ and at streamgage 05388250 Upper Iowa River near Dorchester, Iowa, the NWS flood stage is $14 \mathrm{ft}$, discharge 6,920 ft $3 / \mathrm{s}$ (http://www.crh.noaa.gov/ahps2/hydrograph.php ? wfo $=$ arx \&gage $=$ dchi4\&view $=1,1,1,1,1,1$, accessed February 1,2010). The NWS has not determined a flood stage at streamgage 05387440 Upper Iowa River at Bluffton, Iowa.

\section{Flood Profile}

The USGS located and measured the elevations of HWMs at 15 locations along the Upper Iowa River to develop a flood profile (fig. 1). The profile is 124 river miles from State Highway 26 near the mouth of the Upper Iowa River at the Mississippi River to U.S. Highway 63 at Chester, Iowa. The HWM locations include all Federal and State numbered highway bridges and several county and local road bridges.

The HWMs were flagged within 3 days of the flood and surveyed to a bench mark at each location within 10 days. The HWMs were flagged on both the upstream and downstream sides of the bridges. The upstream marks were located about one bridge length from the bridge to avoid drawdown effects from channel contraction, and the downstream marks were located immediately downstream from the bridge. Bridge deck, bridge low-chord, and low-flow reference-point elevations also were measured with respect to the bench marks. The low-flow reference points were established so that watersurface elevations could be measured during a period when the streamflow was not directly affected by rainfall. All elevations were subsequently referenced to the National Geodetic Vertical Datum of 1929 (NGVD 1929) by surveying level lines to the bench marks from other established bench marks or by using global positioning system (GPS) technology. The bench marks and reference points used in this study and a brief discussion regarding the elevation-measurement methods are presented in an appendix to this report.

The locations of the HWMs were measured in river miles from the mouth of the Upper Iowa River at the Mississippi River. The distances to all locations were determined in a previous study (Eash, 2003). The HWM locations and elevations are listed in table 3.

The HWMs are plotted in a flood profile in figure 3. The profile is expanded in figures 4 and 5 , where the locations also are annotated. The line connecting the HWMs in the figures approximates the high-water surface between the marks. This line does not account for any features between the surveyed HWM locations that may have affected highwater elevations during the flood, such as channel morphology and bridges where HWMs were not measured. In particular, HWMs were not measured at two lowhead dams that are located between the Lundy Bridge Road bridge and Clay Hill Road bridge ("Lower Dam," http://www.iowawhitewater. org/lhd/LHDuilower.html and "Upper Dam," http://www. 
Table 3. Locations and elevations of high-water marks used in the Upper lowa River flood profile, flood of June 8-9, 2008.

[HWM, high-water mark; NGVD 1929, National Geodetic Vertical Datum of 1929; --, not applicable]

\begin{tabular}{|c|c|c|c|}
\hline $\begin{array}{l}\text { Distance upstream } \\
\text { from mouth } \\
\text { (river miles) }\end{array}$ & Location & $\begin{array}{c}\text { Downstream } \\
\text { HWM, } \\
\text { in feet } \\
\text { (NGVD 1929) }\end{array}$ & $\begin{array}{c}\text { Upstream } \\
\text { HWM, } \\
\text { in feet } \\
\text { (NGVD 1929) }\end{array}$ \\
\hline 3.25 & State Highway 26, south of New Albin & 635.94 & 637.57 \\
\hline 12.01 & $\begin{array}{l}\text { Lycurgus Road, adjacent to intersection with } \\
\text { Iowa River Drive (County Road X20) }\end{array}$ & 658.97 & 660.02 \\
\hline 18.28 & $\begin{array}{l}\text { State Highway 76, south of Dorchester; } \\
\text { streamgage } 05388250\end{array}$ & 682.46 & 683.91 \\
\hline 31.27 & Ellingson Bridge Drive (County Road W60) & 734.37 & 736.33 \\
\hline 38.57 & Lundy Bridge Road & 771.01 & 771.73 \\
\hline 52.49 & Clay Hill Road (Freeport Bridge) & 838.94 & 844.01 \\
\hline 56.98 & College Drive, Decorah & 865.73 & 866.61 \\
\hline 57.09 & Streamgage 05387500 , Decorah & 867.90 & -- \\
\hline 59.11 & U.S. Highway 52, Decorah & 878.66 & 881.78 \\
\hline 73.88 & $\begin{array}{l}\text { Bluffton Road, east of Bluffton; streamgage } \\
05387440\end{array}$ & 961.04 & 966.20 \\
\hline 83.40 & Cattle Creek Road & $1,018.05$ & $1,018.53$ \\
\hline 91.52 & State Highway 139 , Kendallville & $1,062.68$ & $1,063.94$ \\
\hline 105.47 & $\begin{array}{l}\text { Victory Avenue (County Road V58), } \\
\text { Florenceville }\end{array}$ & $1,135.13$ & $1,137.87$ \\
\hline 119.42 & $\begin{array}{l}\text { Oak Avenue (County Road V36), north of } \\
\text { Lime Springs }\end{array}$ & $1,199.95$ & $1,200.45$ \\
\hline 127.42 & U.S. Highway 63 , Chester & $1,220.58$ & $1,220.93$ \\
\hline
\end{tabular}




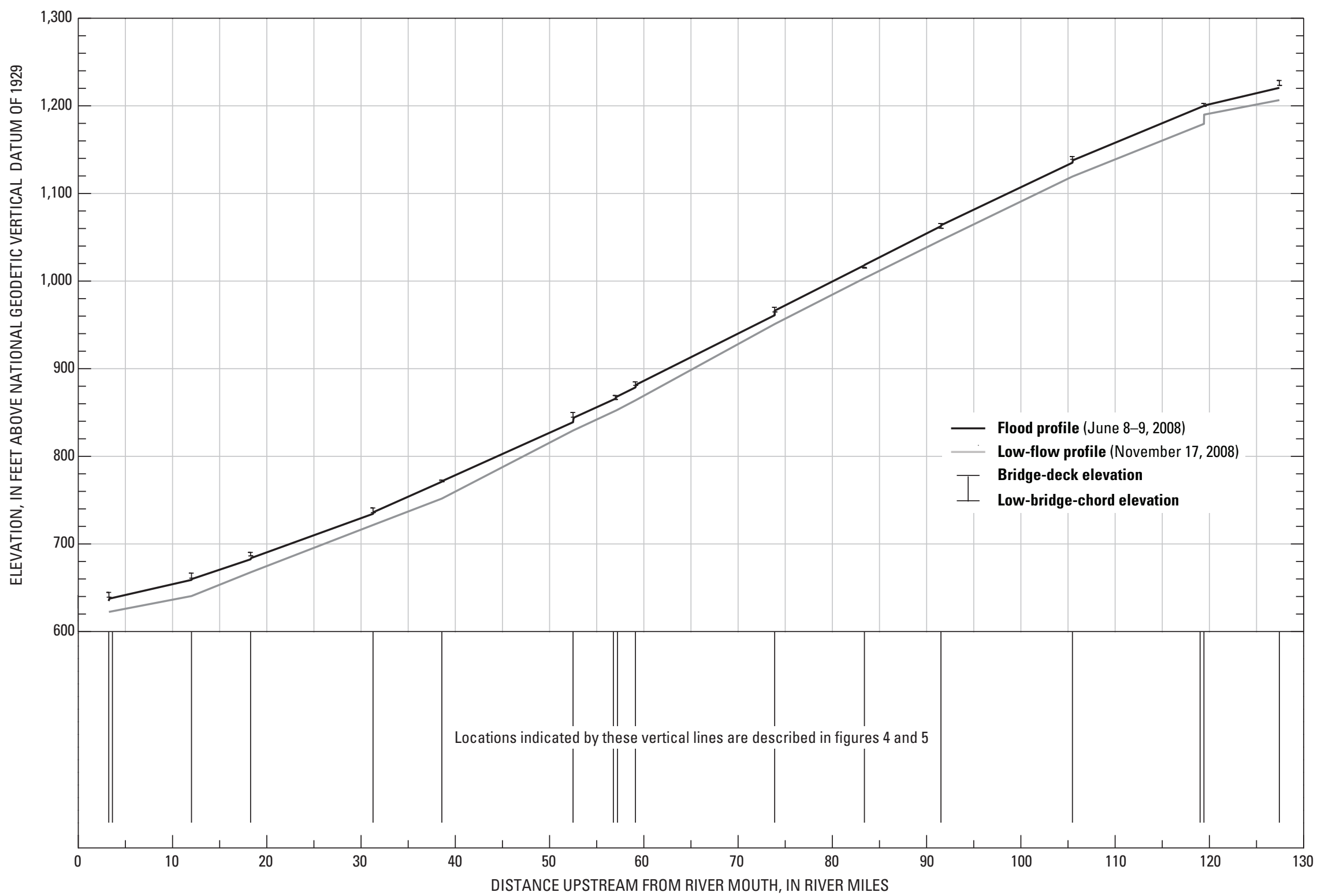

Figure 3. Profile of the June 8-9, 2008, flood in the Upper lowa River, river miles 3 to 127 


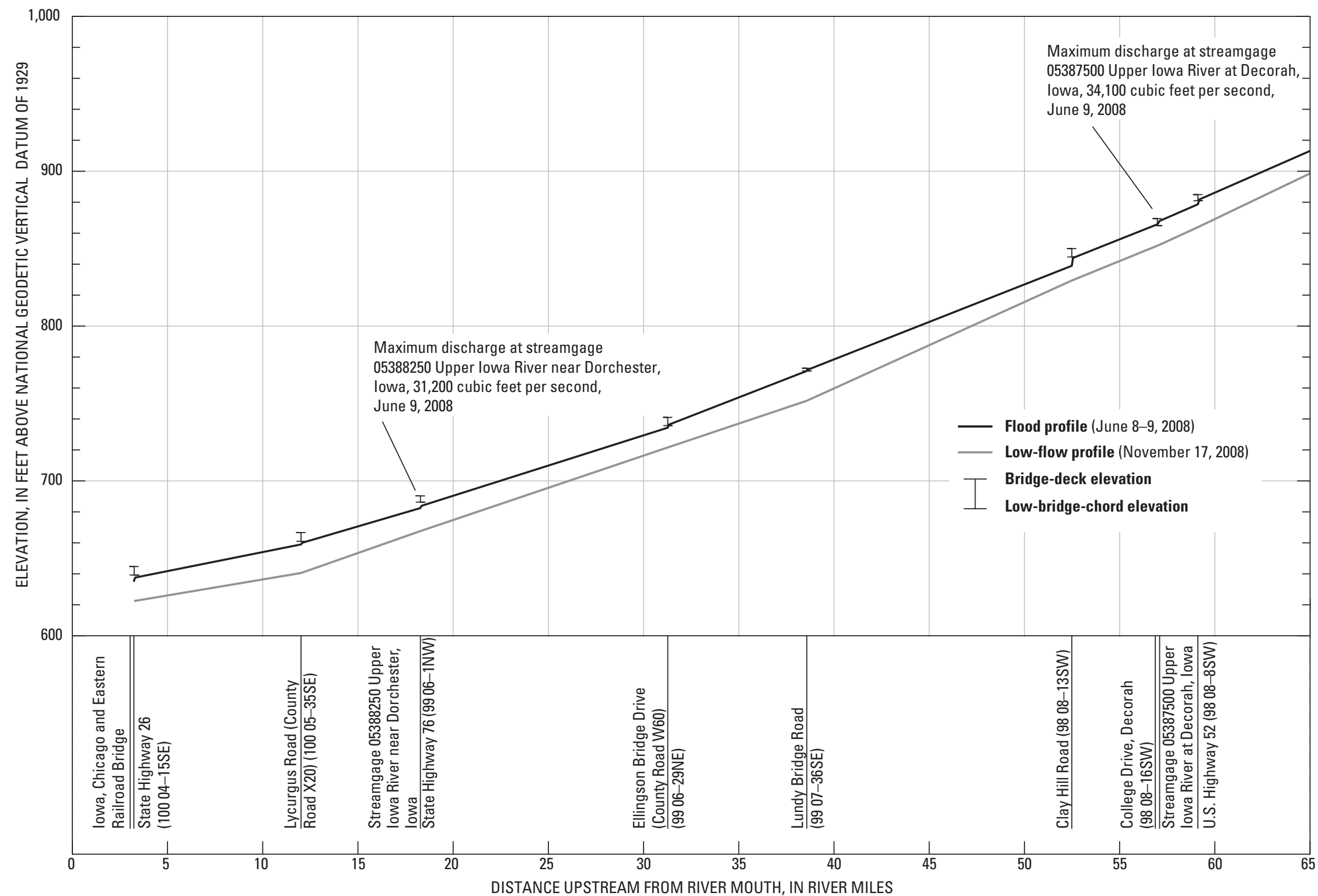

Figure 4. Profile of the June 8-9, 2008, flood in the Upper lowa River, river miles 3 to 65. 


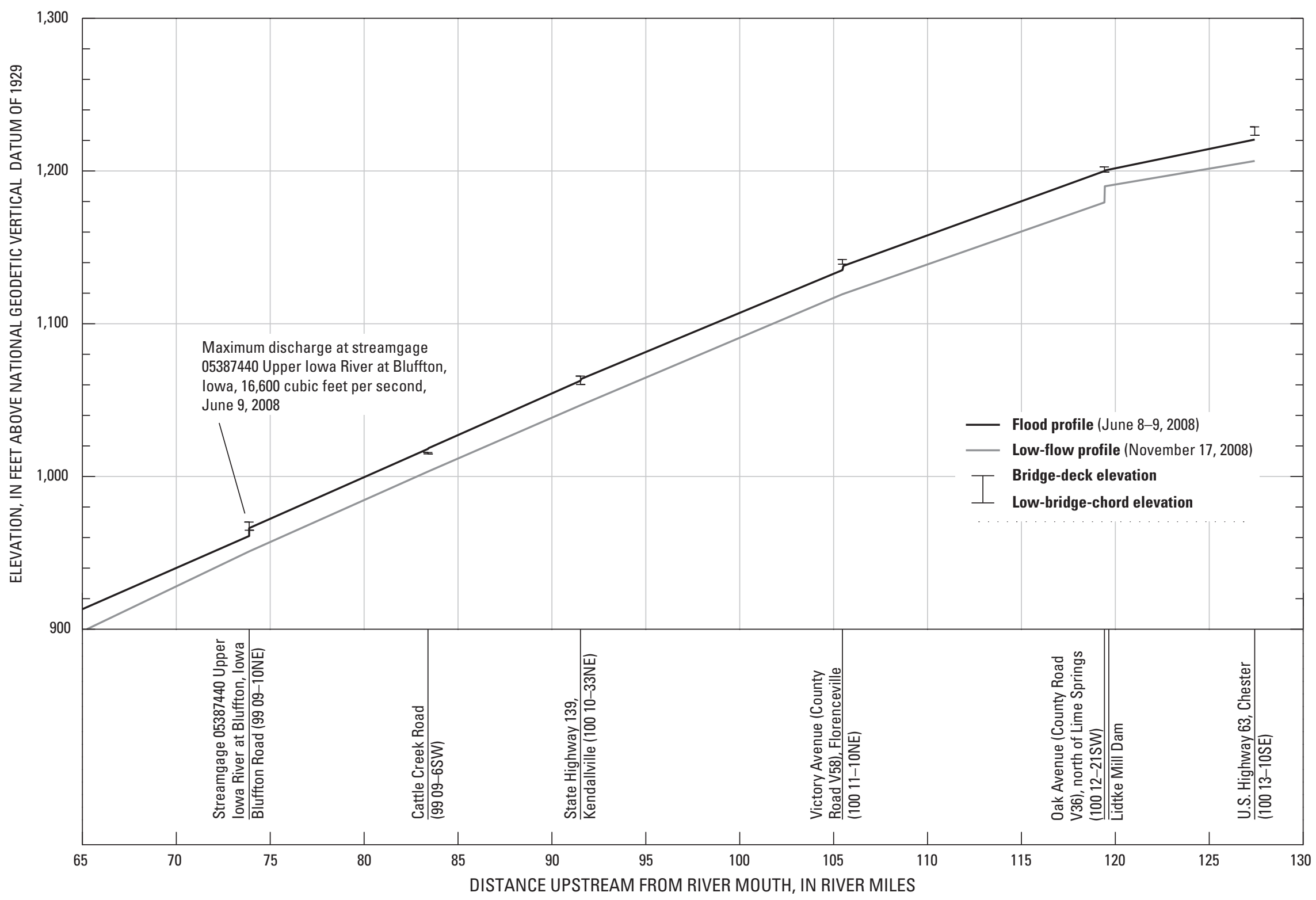

Figure 5. Profile of the June 8-9, 2008, flood in the Upper lowa River, river miles 65 to 127. 
iowawhitewater.org/lhd/LHDuiupper.html, both accessed April 16, 2009). The lower line in the figures represents approximate low-flow conditions and connects the water-surface elevations that were measured November 17, 2008. The low-flow line also approximates the water surface between measurement locations.

Only bridges where HWMs were measured are shown in the figures. They are symbolized by an I-beam symbol where the bottom flange represents the lowest elevation of the low chord and the top flange represents the elevation of the bridge deck above the lowest low chord.

\section{Summary}

The Upper Iowa River in northeast Iowa flooded throughout most of the basin June 8-9, 2008, following severe thunderstorm activity over northeast Iowa and southeast Minnesota. Nearly 7 inches of rain were recorded by 4 p.m., June 8 , for the preceding 48 hours at Decorah, Iowa, and more than 7 inches of rain were recorded by 7 a.m., June 8 , for the preceding 48 hours at Dorchester, Iowa. Peak discharges of record were recorded at all three streamgages on the Upper Iowa River. A maximum peak discharge of $34,100 \mathrm{ft}^{3} / \mathrm{s}$ was recorded at streamgage 05387500 Upper Iowa River at Decorah, Iowa. This discharge is the largest discharge recorded in the Upper Iowa River Basin since streamgaging operations began in the basin in 1914. The flood-probability range of the peak discharge is 0.2 - to 1-percent. High-water marks measured at 15 locations along the Upper Iowa River were presented in a flood profile between State Highway 26 near the mouth at the Mississippi River and U.S. Highway 63 at Chester, Iowa. The length of the profile is 124 river miles.

\section{References Cited}

Christiansen, D.E., and Eash, D.A., 2008, Flood-plain study of the Upper Iowa River in the vicinity of Decorah, Iowa: U.S. Geological Survey Scientific Investigations Map 3005, 1 sheet.
Eash, D.A., 2001, Techniques for estimating flood-frequency discharges for streams in Iowa: U.S. Geological Survey Water-Resources Investigations Report 00-4233, 88 p.

Eash, D.A., 2003, Main-channel slopes of selected streams in Iowa for estimation of flood-frequency discharges: U.S. Geological Survey Water-Resources Investigations Report 03-4120, 215 p.

Hillaker, H.J., 2008, Iowa climate review-June 2008: Des Moines, Iowa Department of Agriculture and Land Stewardship, v. 22, no. 6, 21 p.

Interagency Advisory Committee on Water Data, 1982, Guidelines for determining flood flow frequency: Hydrology Subcommittee Bulletin 17B, 28 p. and app.

Iowa Natural Resources Council, 1958, An inventory of water resources and water problems northeastern Iowa river basins: Des Moines, bulletin 7, 74 p.

Luther College Public Information Office, 2008, College handling Upper Iowa River flooding, accessed January 5, 2009, at http://www.luther.edu/newsDetails.aspx?Channel=/Channels/Admissions + Content\&WorkflowItemID $=28551913$ cd07-485f-ab36-77ea2f5df912.

National Climatic Data Center, 2008, Climate of 2008 midwestern U.S. flood overview: U.S. Department of Commerce, accessed November 2009 at http://www.ncdc.noaa. gov/oa/climate/research/2008/flood08.html.

Natural Resources Conservation Service, 2009, Watershed boundary dataset for Hydrologic Unit Code 07060002, Iowa and Minnesota: U.S. Department of Agriculture, accessed November 21, 2009, at http://datagateway.nrcs.usda.gov/.

Prior, J.C., 1991, Landforms of Iowa: Iowa City, University of Iowa Press, $154 \mathrm{p}$.

U.S. Geological Survey, 2009, Water-resources data for the United States, Water Year 2008: U.S. Geological Survey Water-Data Report WDR-US-2008, site 05388250, accessed November 2009 at http://wdr.water.usgs.gov/ wy2008/pdfs/05388250.2008.pdf. 

Appendix 


\section{Appendix List of bench marks and reference points}

The U.S. Geological Survey (USGS) used the bench marks and reference points listed in appendix table 1 to facilitate measuring the elevations of HWMs, low-flow water surfaces, bridge decks, and bridge low-chords. Temporary bench marks were established at sites where bench marks were not available. In general, bench marks are points that were specifically designed to mark an elevation, such as USGS elevation disks and Iowa Department of Transportation (Iowa DOT) bench marks (round-top rods embedded in concrete at one or more corners of a bridge). Temporary bench marks are marks such as chiseled squares, chiseled arrows, or file marks. Reference points were established above water on the downstream side of each bridge to facilitate measuring low-flow water-surface elevations. Users are cautioned that the bench marks and reference points used for this flood profile might be altered or destroyed since being used in 2008.

The bench marks and reference points are listed in upstream order. Each bench mark is identified by an index number composed of the Public Land Survey System township, range, section number, and quarter-section for each bench mark location. For example, T100N R4W 15 SE means "township 100 north, range 4 west, section 15, southeast quarter-section." Where two or more bench marks/reference points are in the same location, the points are distinguished by a sequence number in parentheses. "Right" and "left" in the descriptions refer to the side of the river determined as an observer looks downstream.

Global positioning system (GPS) technology was used to measure bench-mark/reference-point elevations at each site except where noted otherwise in appendix table 1. The GPS data were collected by the USGS and submitted for processing to Online Positioning User Service (OPUS), an Internet service provided by the National Geodetic Survey (http://www. ngs.noaa.gov/OPUS/). The quality of the GPS data are within the guidelines of "What to look for in a quality solution" on the Internet page titled "What is OPUS?" (http://www.ngs. noaa.gov/OPUS/about.html, accessed November 20, 2009). 
Table 1. Bench marks and reference points used in the Upper lowa River flood profile, flood of June 8-9, 2008.

[Bench marks and reference points are listed in upstream order. NGVD 1929, National Geodetic Vertical Datum of 1929; TBM, temporary bench mark; GPS, Global Positioning System; RP, reference point; BM, bench mark; Iowa DOT, Iowa Department of Transportation]

\begin{tabular}{|c|c|c|c|c|c|}
\hline $\begin{array}{c}\text { Public Land Survey } \\
\text { System } \\
\text { (township, range, section, } \\
\text { quarter-section) }\end{array}$ & $\begin{array}{c}\text { Mark } \\
\text { classification }\end{array}$ & Location & Mark & $\begin{array}{l}\text { Elevation, } \\
\text { in feet } \\
\text { (NGVD 1929) }\end{array}$ & $\begin{array}{l}\text { Elevation } \\
\text { determination } \\
\text { method }\end{array}$ \\
\hline T100N R4W 15 SE (1) & TBM & $\begin{array}{l}\text { About } 2 \text { miles south of New Albin, on State Highway } \\
26 \text { bridge over the main channel (south side of } \\
\text { valley), on left upstream wingwall. }\end{array}$ & Chiseled square & 647.03 & GPS \\
\hline T100N R4W 15 SE (2) & $\mathrm{RP}$ & $\begin{array}{l}\text { About } 2 \text { miles south of New Albin, on State Highway } \\
26 \text { bridge over the main channel (south side of } \\
\text { valley), on downstream side of bridge between } 23 \mathrm{rd} \\
\text { and 24th vertical supports from left end of bridge. }\end{array}$ & Chiseled arrow & 647.20 & GPS \\
\hline T100N R5W 35 SE (1) & $\mathrm{BM}$ & $\begin{array}{l}\text { About } 6 \text { miles southwest of New Albin, on Lycurgus } \\
\text { Road bridge adjacent to the intersection of Iowa } \\
\text { River Drive (County Road A26) and Lycurgus Road, } \\
\text { on left downstream wingwall. }\end{array}$ & $\begin{array}{l}\text { Round-top rod embedded } \\
\text { in concrete }\end{array}$ & 676.44 & GPS \\
\hline T100N R5W 35 SE (2) & $\mathrm{RP}$ & $\begin{array}{l}\text { About } 6 \text { miles southwest of New Albin, on Lycurgus } \\
\text { Road bridge adjacent to the intersection of Iowa } \\
\text { River Drive (County Road A26) and Lycurgus Road, } \\
\text { on downstream barrier wall near 3rd barrier-wall } \\
\text { seam from left end of bridge, about } 4 \text { feet right of } \\
\text { seam. }\end{array}$ & Chiseled arrow & 673.21 & GPS \\
\hline T99N R6W 1 NW & $\mathrm{BM}$ & $\begin{array}{l}\text { About } 3.5 \text { miles south of Dorchester, site of streamgage } \\
\text { 05388250 Upper Iowa River near Dorchester, Iowa, } \\
\text { on State Highway } 76 \text { bridge, on right upstream rail } \\
\text { next to streamgage house. }\end{array}$ & Iowa DOT bench mark & 693.01 & Streamgage elevation data \\
\hline T99N R6W 29 NE (1) & TBM & $\begin{array}{l}\text { About } 3.5 \text { miles west of intersection of Iverson Bridge } \\
\text { Road and State Highway 76, about } 3 \text { miles west of } \\
\text { intersection of Ellingson Bridge Drive and Iverson } \\
\text { Bridge Road, on Ellingson Bridge Drive (County } \\
\text { Road W60) bridge, on left downstream wingwall. }\end{array}$ & Chiseled square & 743.58 & GPS \\
\hline T99N R6W 29 NE (2) & $\mathrm{RP}$ & $\begin{array}{l}\text { About } 3.5 \text { miles west of intersection of Iverson Bridge } \\
\text { Road and State Highway 76, about } 3 \text { miles west of } \\
\text { intersection of Ellingson Bridge Drive and Iverson } \\
\text { Bridge Road, on Ellingson Bridge Drive (County } \\
\text { Road W60) bridge, on downstream handrail at 24th } \\
\text { pillar from left end of bridge. }\end{array}$ & Chiseled arrow & 745.38 & GPS \\
\hline
\end{tabular}


Table 1. Bench marks and reference points used in the Upper lowa River flood profile, flood of June 8-9, 2008. - Continued

[Bench marks and reference points are listed in upstream order. NGVD 1929, National Geodetic Vertical Datum of 1929; TBM, temporary bench mark; GPS, Global Positioning System; $\mathrm{RP}$, reference point; BM, bench mark; Iowa DOT, Iowa Department of Transportation]

\begin{tabular}{|c|c|c|c|c|c|}
\hline $\begin{array}{l}\text { Public Land Survey } \\
\text { System } \\
\text { (township, range, section, } \\
\text { quarter-section) }\end{array}$ & $\begin{array}{c}\text { Mark } \\
\text { classification }\end{array}$ & Location & Mark & $\begin{array}{l}\text { Elevation, } \\
\text { in feet } \\
\text { (NGVD 1929) }\end{array}$ & $\begin{array}{l}\text { Elevation } \\
\text { determination } \\
\text { method }\end{array}$ \\
\hline T99N R7W 36 SE (1) & TBM & $\begin{array}{l}\text { About } 8.5 \text { miles east-northeast of Decorah, on Lundy } \\
\text { Bridge Road bridge, on upstream landward corner } \\
\text { of left upstream abutment adjacent to 6-inch square } \\
\text { hole in the concrete. }\end{array}$ & Chiseled square & 773.32 & GPS \\
\hline T99N R7W 36 SE (2) & $\mathrm{RP}$ & $\begin{array}{l}\text { About } 8.5 \text { miles east-northeast of Decorah, on Lundy } \\
\text { Bridge Road bridge, on downstream handrail be- } \\
\text { tween } 4 \text { th and 5th vertical I-beams from left end of } \\
\text { bridge. }\end{array}$ & Three filed marks & 776.67 & GPS \\
\hline T98N R8W 13 SW (1) & TBM & $\begin{array}{l}\text { At Freeport, on Clay Hill Road bridge on the north side } \\
\text { of town, on right downstream wingwall. }\end{array}$ & Chiseled square & 852.56 & GPS \\
\hline T98N R8W 13 SW (2) & $\mathrm{RP}$ & $\begin{array}{l}\text { At Freeport, on Clay Hill Road bridge on the north } \\
\text { side of town, on downstream barrier wall at 3rd deck } \\
\text { drain from right end of bridge, bottom of bevel (not } \\
\text { top of barrier). }\end{array}$ & Chiseled arrow & 853.39 & GPS \\
\hline T98N R8W 16 SW (1) & TBM & $\begin{array}{l}\text { In Decorah, } 600 \text { feet downstream from streamgage } \\
05387500 \text { Upper Iowa River at Decorah, Iowa, on } \\
\text { College Drive bridge, on right downstream abutment. }\end{array}$ & $\begin{array}{l}\text { Left upstream corner of } \\
\text { concrete light-post ped- } \\
\text { estal (mark not set) }\end{array}$ & 871.73 & $\left({ }^{a}\right)$ \\
\hline T98N R8W 8 SW (1) & TBM & $\begin{array}{l}\text { About } 1 \text { mile west of Decorah, on U.S. Highway } 52 \\
\text { bridge, on left upstream wingwall. }\end{array}$ & Chiseled square & 887.98 & GPS \\
\hline T98N R8W 8 SW (2) & $\mathrm{RP}$ & $\begin{array}{l}\text { About } 1 \text { mile west of Decorah, on U.S. Highway } 52 \\
\text { bridge, on downstream barrier wall between } 7 \text { th and } \\
\text { 8th deck drains from left end of bridge. }\end{array}$ & Chiseled square & 889.75 & GPS \\
\hline T99N R9W $10 \mathrm{NE}$ & BM & $\begin{array}{l}\text { About } 0.5 \text { miles northeast of Bluffton, site of } \\
\text { streamgage } 05387440 \text { Upper Iowa River at Bluffton, } \\
\text { Iowa, on Bluffton Road bridge, on left downstream } \\
\text { wingwall. }\end{array}$ & Chiseled square & 972.69 & Streamgage elevation data \\
\hline T99N R9W 6 SW (1) & TBM & $\begin{array}{l}\text { About } 2.5 \text { miles west northwest of Bluffton, on Cattle } \\
\text { Creek Road bridge, at left downstream abutment, } \\
\text { about } 16 \text { inches below deck level on concrete base } \\
\text { for bridge deck stringers between outer truss beam } \\
\text { and first deck stringer. }\end{array}$ & Chiseled square & $1,016.98$ & $\left({ }^{b}\right)$ \\
\hline
\end{tabular}


Table 1. Bench marks and reference points used in the Upper lowa River flood profile, flood of June 8-9, 2008.-Continued

[Bench marks and reference points are listed in upstream order. NGVD 1929, National Geodetic Vertical Datum of 1929; TBM, temporary bench mark; GPS, Global Positioning System; RP, reference point; BM, bench mark; Iowa DOT, Iowa Department of Transportation]

\begin{tabular}{|c|c|c|c|c|c|}
\hline $\begin{array}{l}\text { Public Land Survey } \\
\text { System } \\
\text { (township, range, section, } \\
\text { quarter-section) }\end{array}$ & $\begin{array}{c}\text { Mark } \\
\text { classification }\end{array}$ & Location & Mark & $\begin{array}{l}\text { Elevation, } \\
\text { in feet } \\
\text { (NGVD 1929) }\end{array}$ & $\begin{array}{l}\text { Elevation } \\
\text { determination } \\
\text { method }\end{array}$ \\
\hline T99N R9W 6 SW (2) & $\mathrm{RP}$ & $\begin{array}{l}\text { About } 2.5 \text { miles west northwest of Bluffton, on Cattle } \\
\text { Creek Road bridge, at downstream 6th vertical } \\
\text { bridge beam from left end of bridge, on steel beam } \\
\text { about } 6 \text { inches below level of bridge deck. }\end{array}$ & Three chiseled marks & $1,018.48$ & $\left({ }^{b}\right)$ \\
\hline T100N R10W 33 NE (1) & $\mathrm{BM}$ & $\begin{array}{l}\text { At Kendallville, on State Highway } 139 \text { bridge, on left } \\
\text { upstream concrete guard rail. }\end{array}$ & Iowa DOT bench mark & $1,070.84$ & GPS \\
\hline T100N R10W 33 NE (2) & $\mathrm{RP}$ & $\begin{array}{l}\text { At Kendallville, on State Highway } 139 \text { bridge, on } \\
\text { downstream concrete guard rail at 6th deck drain } \\
\text { from left end of bridge. }\end{array}$ & Chiseled arrow & $1,068.71$ & GPS \\
\hline T100N R11W 10 NE (1) & TBM & $\begin{array}{l}\text { At Florenceville, on Victory Avenue (County Road } \\
\text { V58) bridge, on left downstream wingwall. }\end{array}$ & Chiseled square & $1,144.96$ & GPS \\
\hline T100N R11W 10 NE (2) & $\mathrm{RP}$ & $\begin{array}{l}\text { At Florenceville, on Victory Avenue (County Road } \\
\text { V58) bridge, on downstream bridge rail between 2nd } \\
\text { and 3rd deck drains from right end of bridge. }\end{array}$ & Chiseled arrow & $1,146.68$ & GPS \\
\hline T100N R12W 21 SW (1) & TBM & $\begin{array}{l}\text { About } 1 \text { mile north of Lime Springs, on Oak Avenue } \\
\text { (County Road V36) bridge, on left upstream wing- } \\
\text { wall. }\end{array}$ & Chiseled square & $1,205.51$ & GPS \\
\hline T100N R12W 21 SW (2) & $\mathrm{RP}$ & $\begin{array}{l}\text { About } 1 \text { mile north of Lime Springs, on Oak Avenue } \\
\text { (County Road V36) bridge, on downstream bridge } \\
\text { rail between 4th and 5th deck drains from left end of } \\
\text { bridge. }\end{array}$ & Chiseled arrow & $1,205.83$ & GPS \\
\hline T100N R12W 20 SE & $\mathrm{RP}$ & $\begin{array}{l}\text { About } 1 \text { mile north of Lime Springs, about } 100 \text { feet up- } \\
\text { stream from Oak Avenue (County Road V36) bridge, } \\
\text { on left upstream wingwall of Lidtke Mill Dam. }\end{array}$ & Chiseled arrow & $1,192.49$ & GPS \\
\hline T100N R13W 10 SE (1) & $\mathrm{BM}$ & $\begin{array}{l}\text { At Chester on U.S. Highway } 63 \text { bridge, on left } \\
\text { upstream wingwall. }\end{array}$ & Iowa DOT bench mark & $1,232.35$ & GPS \\
\hline T100N R13W 10 SE (2) & TBM & $\begin{array}{l}\text { At Chester on U.S. Highway } 63 \text { bridge, on right down- } \\
\text { stream barrier wall adjacent to the wingwall. }\end{array}$ & Chiseled square & $1,231.01$ & GPS \\
\hline T100N R13W 10 SE (3) & $\mathrm{RP}$ & $\begin{array}{l}\text { At Chester on U.S. Highway } 63 \text { bridge, on downstream } \\
\text { barrier wall at } 4 \text { th deck drain from left end of bridge. }\end{array}$ & Chiseled square & $1,233.01$ & GPS \\
\hline
\end{tabular}

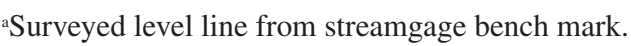

brovided by Winneshiek County Surveyor's Office. 
Publishing support provided by:

Rolla Publishing Service Center

For more information concerning this publication, contact:

Director, USGS lowa Water Science Center

P.O. Box 1230

lowa City, IA 52244

(319) 337-4191

Or visit the lowa Water Science Center Web site at:

http://ia.water.usgs.gov 



